\title{
WATER QUALITY MODEL DESCRIPTION
}

\author{
Erika Ruskule \\ State Environmental Service Rezekne Regional Environmental Board \\ Zemnieku street 5, Rezekne, LV 4601, Latvia \\ Ph.: + (371) 64622597, fax: + (371) 64638215, e-mail: erika.ruskule@ rezekne.vvd.gov.lv
}

\begin{abstract}
Water wise use and conservation is one of the key prerequisites for economic sustainable development. Accession to the European Union, Latvia is committed to meeting the EU environmental requirements. Water Framework Directive (Directive 2000/60/EC, 2000) is a legal act, which provides water protection and sustainable management principles and tasks of the European Union. It provides uniform protection and management system for all waters: rivers, lakes, coastal waters and groundwater, providing that they must also achieve good water quality by 2015. year. The Directive provides for the identification of the current water situation and to obtain additional information by following the water monitoring and for basic background information to establish an action program to improve water quality. Therefore, the Latvian conditions are important to assess the flow of nutrients, their sources and amounts of Latvian detention basins using existing models and innovations in methods and model systems for the retention of part of the calculation. Therefore, in this publication are offered in various countries of the world models will be useful in Latvian processing of data.
\end{abstract} opportunities.

Keywords: monitoring of water, nutrients flow, retention, calculation, mathematical modeling

\section{Introduction}

Geological structure, hydrogeological conditions, climate, land use character and intensity, as well as anthropogenic pollution levels Latvian significantly different from the situation in other countries. Latvian has been quite extensive and long-term studies of water chemistry and water structure analysis, however, these studies have been summarized and critically reviewed. Similarly, until now relatively little Latvian is used in mathematical modeling capabilities that allow analysis of the flow basin sub-basin level, and to identify human activity is causing pressure on surface water quality. In general, the concentration of nutrients in Latvian waters characterized by high turnover, which provides natural and anthropogenic factors interact. Of natural factors have significant effects of climatic conditions and hydrological regime variability, and biotic conditions in the development of a water body. Therefore, the Latvian conditions are important to assess the flow of nutrients, their sources and amounts of Latvian detention basins using existing models and innovations in methods and models of systems and nutrient retention of part of the calculation. To do this, it is necessary to study in Europe and the world of the models offered.

\section{Materials and methods}

Global assessment of nutrients loads are widely used modeling techniques which reflect existing knowledge about the emissions, flows and transformation processes in the catchment and water body. [1, 2, 8, 10] the large number of models provides a growing range of problems, and the fact that models typically are created for a particular catchment area or the region, where other models have not yet been applied. It should be noted that the models are diverse in their capabilities and limitations, so they must be carefully chosen. So far, Latvian diffuse or diffuse modeling calculations used only a few studies (projects) to a defined catchment area or any part in the effective use of limited available data and the lack of research (especially in the last ten years), the model could be adapted to Latvian conditions. Therefore, in order to make calculations for the diffuse distribution of river basin districts, is 
used in the Helsinki Commission "loads to the Baltic Sea (HELCOM PLC) program following recommended methodology. [6;7] It is worth noting - if not available the necessary data and calculations are make certain assumptions, the calculation result obtained approximate figures for the diffuse (mostly forest and farmland-related) and point source pollution in the percentage distribution of river basins. Since the currently lacks the necessary information and the lack of a separate study of the Latvian river basin and the resulting diffuse the results of calculations can be considered as estimates. Water quality models are powerful tools for effective water management and planning. Large number of models provides a growing range of problems, and the fact that conventional models are created for a particular catchment area or the region, where other models have not yet been applied.

Table 1.

Water quality models in Europe

\begin{tabular}{|l|l|l|l|l|}
\hline $\begin{array}{l}\text { Model } \\
\text { name }\end{array}$ & Origin & $\begin{array}{l}\text { European applications } \\
\text { (Nation) }\end{array}$ & $\begin{array}{l}\text { Purpose / } \\
\text { Substances modelled }\end{array}$ & $\begin{array}{l}\text { Process } \\
\text { description }\end{array}$ \\
\hline AGNPS & $\begin{array}{l}\text { USDA; } \\
1987\end{array}$ & $\begin{array}{l}\text { AUT, BE, CH, CZ, DE, } \\
\text { DK, ESP, FI, FR, HU, } \\
\text { IRL, IT, LTU, NL, POL, } \\
\text { PRT, RUS, SVK, UK }\end{array}$ & nutrients, pesticides & conceptual \\
\hline HBV-N & $\begin{array}{l}\text { SMHI; } \\
1994\end{array}$ & SE, EST & $\begin{array}{l}\text { eutrophication control } \\
\text { / nitrogen transport }\end{array}$ & conceptual \\
\hline INCA & $\begin{array}{l}\text { Univ. of } \\
\text { Reading; } 1998\end{array}$ & $\begin{array}{l}\text { UK, FI, NO, DE, DK, NL, } \\
\text { FR, ESP }\end{array}$ & $\begin{array}{l}\text { eutrophication control } \\
\text { / nitrogen transport }\end{array}$ & $\begin{array}{l}\text { conceptual / } \\
\text { mechanistic }\end{array}$ \\
\hline MAGIC & $\begin{array}{l}\text { Univ. of } \\
\text { Virginia; } 1985\end{array}$ & UK, NO, DE, ESP, FI & $\begin{array}{l}\text { acidification control / } \\
\text { nitrogen transport }\end{array}$ & $\begin{array}{l}\text { conceptual / } \\
\text { mechanistic }\end{array}$ \\
\hline MERLIN & $\begin{array}{l}\text { Univ. of } \\
\text { Virginia; } 1997\end{array}$ & UK, SE, NL, NO & $\begin{array}{l}\text { acidification control / } \\
\text { nitrogen transport }\end{array}$ & conceptual \\
\hline $\begin{array}{l}\text { MIKE } \\
\text { SHE }\end{array}$ & $\begin{array}{l}\text { DHI; } 1993 \\
\text { BE, CH, DE, DK, CZ, } \\
\text { ESP, FR, GR, HRV, HU, } \\
\text { IT, LTH, NL, NO, POL, } \\
\text { SVK, SLO, SE, UK, YU }\end{array}$ & $\begin{array}{l}\text { eutrophication control } \\
\text { pollutant transport, } \\
\text { nitrogen transport }\end{array}$ & mechanistic \\
\hline SHETRAN & $\begin{array}{l}\text { Univ. of } \\
\text { Newcastle; } \\
1996\end{array}$ & UK, ESP, FR, IT, PRT & $\begin{array}{l}\text { pollutant control / } \\
\text { sediment and nitrogen } \\
\text { transport }\end{array}$ & mechanistic \\
\hline SMART & $\begin{array}{l}\text { Wageningen } \\
\text { UR; } 1989\end{array}$ & $\begin{array}{l}\text { FI, NL, CZ, TUR, RUS, } \\
\text { ESP, AUT }\end{array}$ & acidification control & mechanistic \\
\hline SWAT & $\begin{array}{l}\text { USDA; 1993 } \\
\text { 13 European countries e.g., } \\
\text { IT, DE, UK, BE }\end{array}$ & $\begin{array}{l}\text { eutrophication and } \\
\text { pesticide control } \\
\text { /sediment, nutrients, }\end{array}$ & conceptual \\
\hline
\end{tabular}

AGNPS (Agricultural Non-Point Source pollution model) - a model developed to examine the water quality as affected by soil erosion from agricultural and urban areas. AGNPS has three major components: hydrology, soil erosion and nutrient pollution.

HBV-N - simulate nitrogen leaching and transport through the groundwater, river and lake systems.

INCA (Integrated Nitrogen in Catchments) - Using the mass balance and reaction kinetics, INCA model composed of several sources of $\mathrm{N}$ and $\mathrm{N}$ of the principle of mechanism, including mineralization, immobilization, nitrification and denitrification.

MAGIC (Model of Acidification of Groundwater in Catchments) - a dynamic model of soil and water acidification can reconstruct and predict the catchment scale.

MERLIN (Model of Ecosystem Retention and Loss of Inorganic Nitrogen) - C and N cycle in ecosystems. 
SHE (Système européen Hydrologique) - modeling system, which describes the main land hydrological cycle-flow processes. With regard to water quality modeling, SHE was first used in the modeling of nitrogen.

MIKE SHE - a dynamic simulation tool for analysis, planning and management, large water resources and environmental problems associated with surface water and groundwater, particularly where there is human intervention.

SMART (Simulation Model for Acidification's Regional Trends) - It is a simple soil acidification and nutrient cycle model that includes the main hydrological and biogeochemical processes.

SWAT (Soil and Water Assessment Tool) - There is a complex conceptual model. It is a continuous-time model, which operates daily during the period, the model is designed to control the impact of decisions on water, sediment, nutrient and pesticide yields with reasonable accuracy river basins. $[4,12,13,14,15]$

Table 2.

Water quality models for soil water and field scale in Europe

\begin{tabular}{|c|c|c|c|c|}
\hline $\begin{array}{l}\text { Model } \\
\text { name }\end{array}$ & Origin & $\begin{array}{l}\text { European } \\
\text { applications } \\
\text { (Nation) }\end{array}$ & $\begin{array}{l}\text { Purpose / } \\
\text { Substances modelled }\end{array}$ & $\begin{array}{l}\text { Process } \\
\text { description }\end{array}$ \\
\hline ANIMO & $\begin{array}{l}\text { Wageningen UR; } \\
1991\end{array}$ & $\begin{array}{l}\text { BE, CH, DE, DK, CZ, } \\
\text { FR, IT, NL, NO, } \\
\text { POL, RUS, SLO, UK }\end{array}$ & $\begin{array}{l}\text { nitrogen leaching to } \\
\text { groundwater }\end{array}$ & mechanistic \\
\hline EPIC & USDA; 1984 & FR, DE, UK & $\begin{array}{l}\text { soil erosion, nutrient } \\
\text { cycling, pesticide fate, } \\
\text { agricultural economics }\end{array}$ & conceptual \\
\hline GLEAMS & USDA; 1987 & $\begin{array}{l}\text { FI, POL, DE, SE, } \\
\text { RUS, UK, CZ }\end{array}$ & agricultural pollutants & conceptual \\
\hline $\begin{array}{l}\text { HYDRUS } \\
\text { / SWMS }\end{array}$ & USDA; 1996 & $\begin{array}{l}\text { AUT, BE, DK, FR, } \\
\text { DE, IT, NL, POR, } \\
\text { ESP, SE, CH, UK }\end{array}$ & $\begin{array}{l}\text { solute transport in } \\
\text { porous media }\end{array}$ & mechanistic \\
\hline MACRO & $\begin{array}{l}\text { Swe. Univ. } \\
\text { Agric.Scien.; } 1994\end{array}$ & SE, SP, DE, UK & $\begin{array}{l}\text { solute transport in } \\
\text { arable soils }\end{array}$ & mechanistic \\
\hline PEARL & Alterra, NL; 2000 & NL, SE, IT & pesticide leaching & $\begin{array}{l}\text { conceptual } \\
\text { / } \\
\text { mechanistic }\end{array}$ \\
\hline PRZM & US EPA; 1984 & \multicolumn{2}{|c|}{ pesticide movement } & mechanistic \\
\hline SOILN & $\begin{array}{l}\text { Swe. Univ. } \\
\text { Agric.Scien.; } 1987\end{array}$ & SE, NO, FI, DK, EST & $\begin{array}{l}\text { nitrogen leaching from } \\
\text { arable soils }\end{array}$ & mechanistic \\
\hline WAVE & Univ. Leuven; 1995 & BE, NL, TUR & soil chemical transport & mechanistic \\
\hline
\end{tabular}

ANIMO (Agricultural Nitrogen Model) - dynamic model of carbon, nitrogen and phosphorus cycles, and saturated and unsaturated soil systems. This model has been developed for the analysis of nitrogen leaching from the soil surface, groundwater and surface water.

EPIC (Erosion- Productivity Impact Calculator) - This model has been developed to assess the impact of soil erosion on soil productivity.

Gleams (Groundwater Loading Effects of Agricultural Management Systems) - It has four major components: hydrology, erosion, sediment yield, pesticide transport, and nutrients.

HYDRO / SWMS - environmental modeling water flow analysis, and solute transport porous. MACRO - The mathematical model of water flow and reactive solute transport in soil PEARL (Pesticide Emission Assessment at Regional and Local scales) - have been used for pesticide registration procedure. 
PRZM (Pesticide Root Zone Model) - This model consists of the hydrological (flow) and chemical components of transport channels to simulate the erosion, leaching, decay, etc.

SOILN (or Coupe Model) - Model description of nitrogen dynamics and losses in the soil profile of agricultural lands.

WAVE (Water and Agrochemicals in the Soil, Crop and Environment Lead) - describes a substance transport and energy transformations in the soil and the soil. $[4,5,6,9,11]$

Table 3.

Water quality models to groundwater in Europe

\begin{tabular}{|l|l|l|l|l|}
\hline Model name & Origin & $\begin{array}{l}\text { European applications } \\
\text { (Nation) }\end{array}$ & $\begin{array}{l}\text { Purpose / } \\
\text { Substances modelled }\end{array}$ & $\begin{array}{l}\text { Process } \\
\text { description }\end{array}$ \\
\hline $\begin{array}{l}\text { ASM/ASMW } \\
\text { IN }\end{array}$ & ETH; 1986 & CH & pollution dispersion & mechanistic \\
\hline $\begin{array}{l}\text { MODFLOW } \\
\text { /MT3D/RT3 } \\
\text { D }\end{array}$ & USGS; 1988 & $\begin{array}{l}\text { e.g. NL, DE, FR, IT, SE, } \\
\text { UK }\end{array}$ & $\begin{array}{l}\text { groundwater flow, } \\
\text { solute transport }\end{array}$ & mechanistic \\
\hline
\end{tabular}

ASM / ASMWIN (Aquifer Simulation Model / for Windows) - is a horizontal or vertical, twodimensional groundwater flow and transport model.

MODFLOW/MT3D/RT3D - is used to simulate the water supply system. [9, 13, 14, 15, 16, 17]

Water quality models for lakes in Europe

\begin{tabular}{|l|l|l|l|l|}
\hline Model name & Origin & $\begin{array}{l}\text { European } \\
\text { applications } \\
\text { (Nation) }\end{array}$ & $\begin{array}{l}\text { Purpose / } \\
\text { Substances } \\
\text { modelled }\end{array}$ & $\begin{array}{l}\text { Process } \\
\text { description }\end{array}$ \\
\hline $\begin{array}{l}\text { DELWAQ- } \\
\text { BLOOM- } \\
\text { SWITCH } \\
\text { (DBS) }\end{array}$ & RIZA; 1994 & $\begin{array}{l}\text { NL, Danube } \\
\text { countries }\end{array}$ & $\begin{array}{l}\text { eutrophication } \\
\text { management }\end{array}$ & mechanistic \\
\hline DYRESM & $\begin{array}{l}\text { Centre for Water } \\
\text { Research, University } \\
\text { of Western Australia; } \\
1980\end{array}$ & $\begin{array}{l}\text { BIH, FI, FR, DE, } \\
\text { GR, IT, NL, NO, } \\
\text { POL, PRT, ESP, } \\
\text { SE, CH, TUR, } \\
\text { UK }\end{array}$ & $\begin{array}{l}\text { hydrodynamics } \\
\text { and water quality } \\
\text { in lakes and } \\
\text { reservoirs }\end{array}$ & mechanistic \\
\hline LIMNOD & $\begin{array}{l}\text { Eldgenössische } \\
\text { Technische } \\
\text { Hochschule, Zürich, } \\
\text { Switzerland; 1992 }\end{array}$ & CH & $\begin{array}{l}\text { lake management } \\
\text { and scenario } \\
\text { modelling }\end{array}$ & mechanistic \\
\hline $\begin{array}{l}\text { PC-LAKE } \\
\text { (PCLOOS) }\end{array}$ & LWD; 1992 & NL & $\begin{array}{l}\text { eutrophication } \\
\text { management }\end{array}$ & mechanistic \\
\hline PH-ALA & $\begin{array}{l}\text { Univ. of Rome, Italy; } \\
1996 \text { (?). }\end{array}$ & IT & $\begin{array}{l}\text { eutrophication } \\
\text { trend analysis }\end{array}$ & mechanistic \\
\hline
\end{tabular}


Table 5.

Water-quality samples of urban rainwater in Europe

\begin{tabular}{|l|l|l|l|l|}
\hline $\begin{array}{l}\text { Model } \\
\text { name }\end{array}$ & Origin & $\begin{array}{l}\text { European } \\
\text { applications } \\
\text { (Nation) }\end{array}$ & $\begin{array}{l}\text { Purpose / } \\
\text { Substances modelled }\end{array}$ & $\begin{array}{l}\text { Process } \\
\text { description }\end{array}$ \\
\hline MOUSE & DHI; 1980's & $\begin{array}{l}\text { distributed to all } \\
\text { European countries, } \\
\text { but unclear if used for } \\
\text { water quality } \\
\text { modelling }\end{array}$ & $\begin{array}{l}\text { water quality and } \\
\text { sediment transport } \\
\text { modelling package for } \\
\text { urban drainage systems, } \\
\text { storm water sewers and } \\
\text { sanitary sewers }\end{array}$ & mechanistic \\
\hline SWMM & $\begin{array}{l}\text { US EPA; } \\
\text { 1970's }\end{array}$ & $\begin{array}{l}\text { CZ, DK, FR, IT, } \\
\text { ROM, ESP, SE, but } \\
\text { unclear if used for } \\
\text { water-quality } \\
\text { modelling }\end{array}$ & $\begin{array}{l}\text { all aspects of the urban } \\
\text { hydrologic and quality } \\
\text { cycles, including rainfall, } \\
\text { snowmelt, surface and } \\
\text { subsurface runoff, flow } \\
\text { routing through drainage } \\
\text { network, storage and } \\
\text { treatment }\end{array}$ & mechanistic \\
\hline
\end{tabular}

Hydrology Models

MIKE model families. These are the Danish Hydraulic Institute (DHI) has developed physically reasonable models (MIKE 11, MIKE FLOOD, MIKE 21, MIKE Basin. Model operation requires a comprehensive and detailed information about the river basin.

HBV model

HBV model developed in the Swedish Meteorology and hydrology Institute (SMHI), 20th century 70 years old at the beginning, it was created by Professor S. Bergstrom. The model has many different variations. The advantage for the Nordic countries - it is believed that this pattern is best developed in the snow melting / formation scheme. Rain, snow, air temperature is used as raw data for calculating the water flow rate.

Channel general water can be described as follows:

$$
P-E-Q=\frac{d}{d t}[S P+S M+U Z+L Z+\text { lakes }]
$$

The various versions of the HBV model has been applied in over 40 countries worldwide. It is suitable for countries with so different climatic conditions, such as Sweden, Zimbabwe, India and Colombia. HBV can be used as a semi-distributed model. Each area is divided into zones according to altitude, lake area and vegetation. The model is usually open every day for rainfall and temperature calculation, as well as daily and monthly estimates of potential evaporation. Model is used for flood forecasting in the Nordic countries, and many other purposes such as flood modeling, water resources assessment collection, nutrient load calculation.

Input data are observations of precipitation, air temperature and estimates of potential evapotranspiration. For example, proposed in the literature: [5, 13] 


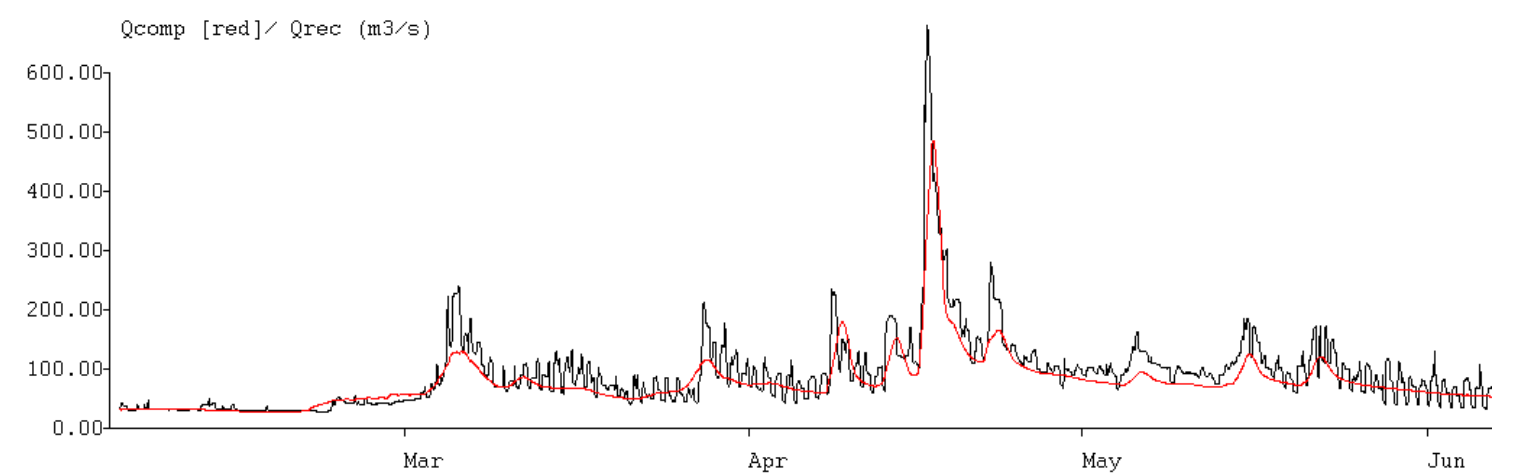

Figure 1. Obtained (Qrec) and calculated (Ocomp) A comparison of data at 1 hour of inundation model

\section{SWAT model}

The model aims to: provide for and determine the impact of economic activities on water quality, provide for the consequences of various business-to-water, sediment, certain nutrients, pesticides and large quantities of $\mathrm{N}$ in closed basins. In studies using data on weather conditions, surface runoff, flow, infiltration, ET, transmission losses, pond and reservoir location, grain yield and irrigation, groundwater flow, nutrient and pesticide use, water movement. [17]

Fyris model

There was the 1996th in Sweden to determine the characteristic of river nutrients (nitrogen and phosphorus) pollution load distribution, and retention (retention) factor FRYS river in central Sweden. Since the case of river basins divided into homogeneous fractional basins, which represent the hydrochemical monitoring of water quality measurement points.
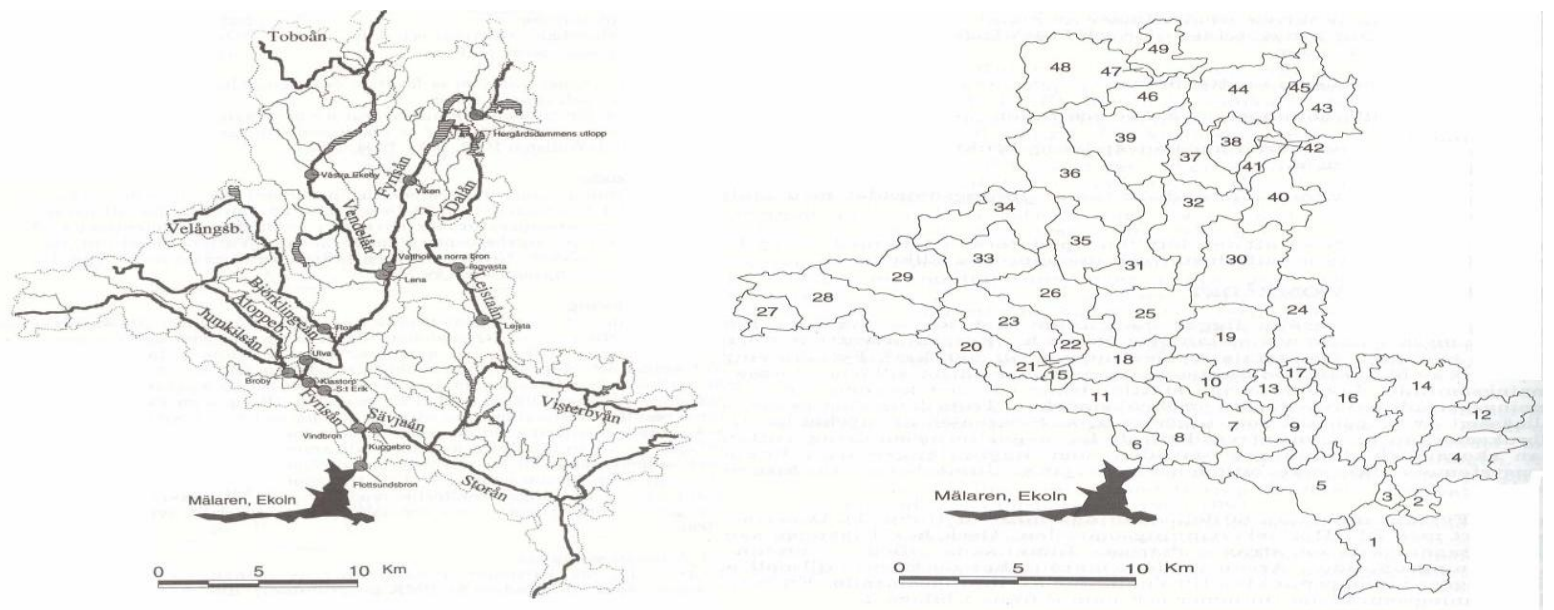

Figure 2. River basin fractional basins [15]

\section{Results and analysis}

Loads of biogenic elements and flow of the assessment can be used for statistical and dynamic models. Statistical models based on regression analysis, for example, between the observed concentrations of nutrients and water flow rate, or between the observed nutrients loads and catchment characteristics. Dynamic model conceptually describes the physical, chemical and biological processes in the catchment and water and nutrients simulate load and water flow rate. Dynamic models can be used for water quality forecasting purposes. [3] From the HELCOM PLC guidelines, for a given river basin in diffuse or diffuse pollution discharged to surface waters from the mainland, Latvian at the expense of two ways: (1) where it is 
monitored in all diffuse and point source pollution load of the river basin, the result can be calculated by the river load (2) if the monitored river and separate the diffuse and point sources of pollution of the river basin. In my opinion, would be applicable in Latvia HBV model for nutrient load calculation [6].

\section{METQ model}

Latvian since the late 80th years of groundwater regime and runoff mathematical modeling is used in conceptual models and METUL METQ family. On the input data used in daily meteorological observations. So far, the model is successfully calibrated for both large (the Daugava, Salaca), although some small river basins. Develops over time METQ model, it has been several versions (METQ96, METQ98, METQ2005, METQ2006). Model is the latest version of METQ2007BDOPT with semi-automatic calibration feature. It is possible to calibrate a conceptual model METQ2007BDOPT with different values describing the pool surface climatic and geomorphologic conditions Latvian river basins, which have been terminated or will continue to hydrologic comments Model METQ a conceptual mathematical model with the use of variable sites (distributed) parameters. METQ conceptual model has the following user options: ground and surface water runoff (including runoff transformation) estimates of snow accumulation and melt modeling. Using this model, it is possible to calculate hydrological variables - the average daily flow rate. Of the simulated and observed flow rate reproducibility indices have been adopted by the statistical criterion $\mathrm{R} 2$, correlation coefficient $r$ and the average permanent drainage basin. River District runoff process model representing the four main calculations: snow formation and ablation, the active soil layer balance, ground water and the inside layer of the balance sheet as well as runoff transformation parts of the basin drainage network. River basin or parts of the basin a space less than $2000 \mathrm{~km} 2$, which is not large lake or broad flood plain with a large pop-regulating capacity, can be considered as linear hydrological system and the relationship between the output can be described by linear differential equations with concentrated or fixed parameters. Conversely, if the lake basin, the drainage basin of such a transformation is calculated with the hydraulic methods. In Mode total runoff is characterized by the following components surface runoff (Q1) and groundwater runoff, which in turn divided into the upper layer of groundwater runoff $(\mathrm{Q} 2)$ and the lower layer groundwater runoff $(\mathrm{Q} 3)$. Surface runoff can be divided into two groups depending on the underlying frameworks: infiltration excess runoff, or Horton runoff: soil saturation runoff, which occurs when the soil is saturated with water to land surface. In Model METQ2007BDOPT is divided up into three different types of water collections: collections of moisture in the snow, Stocks soil moisture on the active layer moisture and groundwater stocks capillary-off layer. [6 7]

\section{Summary}

Latvian circumstances, it is important to assess the flow of nutrients, their sources and amounts of detention basins, using existing models and innovations in methods and model systems for the retention of part of the calculation. Therefore, in this publication are offered in various countries of the world models will be useful in Latvian processing of data and approbation.

\section{References}

1. Arheimer B., Brandt M. (1998) Modelling nitrogen transport and retention in the catchments of southern Sweden. Ambio 27(6), 471-480.

2. Clark M.J., Cresser M.S., Smart R., Chapman P.J., Edwards A.C. (2004) The influence of catchment characteristics on the seasonality of carbon and nitrogen species concentrations in upland rivers of Northern Scotland. Biogeochemistry 68, 1-19.

3. Grimvall A., Stalnacke P. (1996) Statistical methods for source apportionment of riverine loads of pollutants. Environmetrics 7, 201-213. 
4. Helsel D.R., Hirsch R.M. (1992) Statistical methods in water resources. Amsterdam: Elsevier Science Publ. B.V.

5. Iital A., Stalnacke P., Deelstra J., Loigu E., Pihlak M. (2005) Effects on large-scale changes in emissions on nutrient concentrations in Estonian rivers in the Lake Peipsi drainage basin. J. Hydrol. 304, 261-273.

6. Jansons V. (2005) Lauksaimniecības noteču monitorings. LLU tēma Nr.13/04 L-105.

7. Kḷaviņš M., Rodinovs V., Kokorīte I. (2002) Chemistry of Surface Waters in Latvia. Rīga:LU, 286 pp.

8. Petersen W., Bertino L., Callies U., Zorita E. (2001) Process identification by principal component analysis of river water-quality data. Ecol.Model. 138, 193-213 26

9. Rantakari M., Kortelainen P., Vuorenmaa J., Mannio J., Forsius M. (2004) Finnish lake survey: the role of catchment attributes in determining nitrogen, phosphorus, and organic carbon concentrations. Water, Air, Soil Pollut.: Focus 4, 683-699.

10. Shrestha S., Kazama F. (2006) Assessment of surface water quality using mulitivariate statistical techniques: A case study of the Fuji river basin, Japan. Environ.Modell.Softw. (in press)

11. Stalnacke P., Vandsemb S.M., Vassiljev A., Grimvall A., Jolankai G. (2004) Changes in nutrient levels in some Eastern European rivers in response to large-scale changes in agriculture. Water, Sci. Technol. 49, 3036.

12. Vassiljev A., Stalnacke P. 2003. Statistical modelling of riverine nutrient sources in the Lake Peipsi drainage basin. Diffuse pollution conference proceedings, Dublin, 41-46.

13. http://iopscience.iop.org/1755-1315/4/1/012004/pdf/ees8_4_012004.pdf

14. http://www.meteo.lv/upload_file/Udens\%20kvalitates\%20modelesanas\%20sistema\%20Lielupes\%20upju\% 20baseina\%20apgabalam.pdf

15. http://kalme.daba.lv/faili/materiali/LU_Zin_konference/Prezentacijas\%20LU65KONF/AbramenkoK_Legz dinsA.pdf

16. www2.llu.lv/homepg/lif/konf/kagm.ppt

17. www2.llu.lv/homepg/lif/konf/vj.pdf 